\title{
This Blanket of Dismemberment
}

\author{
Sarah Murphy
}

\section{Cette couverture du démembrement}

Le sujet de l'énonciation se regarde en elle, le sujet de l'énoncé, l'enfant d'il y a trente ans qui subit l'aggression sexuelle de son frère et de ses amis. Ils la menacent du sort de sa poupée, qu'ils ont démembrée. Elle s'assoit dans un fauteuil avec sa couverture essayant de se détacher de son corps, de se dédoubler.

I will answer your question, then, if you really want me to. Yes, the girl I am watching sitting naked in the chair is me. The person sitting there is me. And she is very cold. Though the chair is big and grey and covered in thick cotton cloth and seems to surround her, her arms out on its arms, held unmoving, still: she is very cold. You can tell that from the gooseflesh along the arms and legs if you look closely. I will not look at the rest of her body, except maybe the protrusion of the ribcage on the left, a birth defect; instead I will cover it all with my thoughts, the way she tried to cover herself leaning forward over her knees, when they told her not to move, Don't move or we'll tie you up, her brother said, so that she smiled. Okay, she said, I told her to, Pretend there is nothing to be afraid of and nothing will happen I told her, uncurling her arms from where they wished to press against her legs and putting them back on the arms of the sofa. Don't worry, I said, so that she said it too. And tried to giggle. The one who was not her brother was masturbating on the couch. She pretended that did not interest her. That it was no more important than the television, or than being cold. If she noticed, maybe they would make her come over again and kiss it, maybe they would want more this time. I make her look at the ceiling.

That helps sometimes. If I make her concentrate on the things around her. The dirt under her fingernails, or the texture of the cotton under her fingers. Even under her bum. Though I don't really like her 
to think about that part of her body, to notice it, or the cold rough cotton with its knots. If she thinks about that she might think about the part in front, exposed to the air now instead of rubbing against the smooth comforting texture of her underwear. And then she might squirm a little and they might think of it too, and ask her to open her legs again so they can look at it more closely. Open up, Sis, her brother might say, and then there's the possibility she might even feel something down there. She does when she plays with it herself, when she's alone. And that's the last thing I would want. So, the wallpaper will do, this time. How the little ribbons curl around the flowers inside their cornucopias, that's a word they just taught me in school, it means horn of riches, like the flowers pouring out. Those should be able to get her through a few minutes.

She seems very small over there. In the middle of that chair. Very very small. Like a doll. And so very skinny. There are no dolls like that. Not yet. Dolls are all fat baby dolls, or adolescent dolls with breasts but no nipples. She has nipples. But no breasts to speak of. Iknow that without looking. I won't look there. Not even for an instant. She would be better off if she were made like the dolls. Smooth plastic from neck to the joints of the thighs. Where her legs come forward. Squeezed together to cover that other part the dolls don't have. To try to pretend she doesn't have it either. The way I tell her to. Perhaps I can make her like that. Or at least make her skinnier. Bend one hip into the chair, the other up toward the lamp, while I curve one shoulder in too, shrinking her.

Stop, don't move, they say.

It's obvious she has not shrunk enough since the last time, even if I have stopped feeding her. Except a little. I let her eat a bit. She keeps saying she wants more, but by now it seems to make her sick. Someone always wants to feed her something rich in iron, liver or spinach, even tomatoes. She's anemic they say. Anemic. Even her brother wants to feed her. Offering her things from his plate. But she just looks. At his plate heaped up with meat and vegetables. Hot dogs or hamburgers. I think she understands now why he wants to fatten her up. Because after a few bites she wants to gag. That's okay. I tell her that's fine. Even if vomiting seems to bother her. And the food she gets seems to be too much anyway. No matter how much I try, I cannot seem to make that new body disappear. Sometimes they even make it 
parade around. Like the models in the Miss Universe pageant. Though those at least get bathing suits.

The wallpaper hasn't been as effective as I thought it might be. I can already hear her start to whine. Deep in her throat it starts. EEEEEYEEE, EEEEEEYEEEE, EEEEEEYEEE, like a siren or a hurt animal, that kitten of hers when it died of distemper, more than like a baby. It's that question coming up again. That question. The one I won't let her ask. Why me? she wants to say, Why me? But I won't let her. Isn't this fun? they'll answer. That's all they ever say. But they never volunteer to take her place. They never have. Even when she was the captive in cowboys and Indians, they never volunteered to get burned at the stake or baked out in the sun. In those days they said Indians did things like that. Even if they should know better since they lived with one. Because you're there, is what I whisper at her times she gets the question out, or tries to. Because you're there. Like that story about climbing mountains. I know about that, too. I'm far more sophisticated than she is. It's because you're there I say, Because you're there. But no matter how many times I tell her, even when I scream at her late at night, and make her food rot in front of her eyes, I can't make her leave. She's stubborn that one. Stubborn. And pitiful really. She just doesn't get it. She won't disappear.

Or stop trying to ask her questions. She's really quite something once she gets going. All that, Why me? Followed by what did I do, followed by what did I do wrong, followed by did I eat too much of his ice cream, is it that I'm better in school, did I visit him too often late at night when people are drinking in the house, is it that I'm a better shot with his bow, did I need someone to talk to, is it that Ilay down next to him, did I look at him pissing in the bathroom did I look at the sex manuals with him did I masturbate in front of the t.v. did I tell him about the boys at the school with their drawings of naked women did I try to draw a penis for him did he watch me do it did his friends watch me do it do I look different why am I different what is this body I'm growing have his friends been watching have they been watching have they been watching all this time have they been watching did they watch me did they watch me did they see me did they see me did they see me did they see how bad I am. How bad I am how bad I am how bad I am how bad I am and her fingers will open and close and sometimes her nails will dig into her palms and she will tear at her 


\section{Tessera}

arms and at her hips and they will notice her and make her do things until she will start to whine again. Always EEEEYEEE EEEEEEEYEEEE EEEEEEEEYEEEE that terrible whine as she rocks back and forth to cover her shame to cover her fear to try to throw it up and out only that doesn't work either. Even when she throws up so little comes out that it can't help her disappear, no matter what I do, I've discovered that.

That's why I've decided that skinny body is indissoluble. That I've got to start working on something else, some kind of new technique. So I start by telling her it's going to be all right. I don't even mention that stuff about how it's because she's there I just tell her it's all right. It gets harder and harder for her to take if you're not gentle with her, sometimes she starts to shake and cry if you're not careful so I have to be very careful, very very careful, because if she does those things something worse will happen, I'm sure of it, they'll tie her up or make her do that thing with his prick again, it's not at all like the one she drew, not really, it's so thick and dry and it smells like pee when she puts it in her mouth even if they promise he won't pee in there still that would give her a real reason to gag just the way she did the last time when she cried too, great big tears, and she sniveled and she had to promise she would do anything they wanted if they just didn't make her do that, so I can't even warn her. Much less make her remember. If I remind her how much worse it might get if she doesn't pretend to go along she might panic, you can see how that's starting to happen anyway, it's not just the cold anymore, not at all, do you notice how her stomach is starting to heave her diaphragm is going into spasm, right there below those breasts I don't want to look at, only they do, god, the nipples are shaking and they're starting to look up, the two sets of eyes are going up and over, away from his prick for a moment, back over to her, so that I send her eyes once more up to the ceiling, Shshsh I say this time Shshshsh, calming the spasm and wishing their eyes away, They won't hurt you, really they won't, they won't hurt you, you'll see, I say, It will be all right, really it will, only I can't get close enough to reach out to her, not from where I am across the room, I have to stay here far away from her so they won't notice me, they won't notice where I've gone. Or how I try to help her.

I've noticed how she likes the colours that explode behind her eyes when she squeezes them shut late at hight when Imake the cookies rot and the voices whisper, Get out, Get out, I make them say, Get out, Get 
out, while she pulls her blankets up around her chin and screams back, I won't go I won't, she doesn't believe me when I tell her it would be better that way, sometimes she screams This is my place so loud that someone comes running up the stairs to see her, times the music isn't too loud for them to hear, or they're out. Even her brother comes sometimes, to comfort her. There, there, they say, There, there, it's going to be all right. She really likes that, that's where I got it from. Then they tell her it's only a nightmare, a bad dream, that she has a fever again, that she's anemic, catching too many colds, You have to promise to eat more they say, sometimes they even hugher. And they turn on the light. Then they go away.

Mostly I don't scream at her then. Though I can still make the cookies and the cakes and the other food and even bodies disintegrate in the grey space in her mind if I really want to. Until she comes to prefer the dark. Times like this in the chair, she longs for it. With its explosive colours, dark blue and purple, with yellow paisley and orange squares and red explosions. Like falling stars or northern lights. So that's what I'll give her. I've been working on this one a long time. It's going to be good. It'll work. Better than punishment. Better than screaming at her. Or even warning her. Better than starving her. You'11 see.

I got the idea from how they tried to warn her once, too. When they took one of her dolls and tore it apart. Dismembered it and put its arms and legs in different parts of her chest of drawers, with the body hung in her closet. This could happen to you, they wrote on its chest. This could happen to you. They meant if she wasn't good. Or if she told. Only she has been good. And I will make sure she never tells. I will dismember her myself now that I know she can't disappear. But this won't be like what they did. It's not a warning. No more rotting cookies, no more whispering voices, not this time. I'm going to make something beautiful. A blanket. I will make her a blanket. A blue and purple blanket. Fluffy like the clothes in the drawer where she found the arms and legs. Even if it will have much less substance, still it will be of just the colours she might see if I could let her close her eyes. The ones she likes so much. So that while she watches them I can close her mind instead. Into silence.

Into this long tunnel where she cannot be hurt, where that blanket will cover her even as she sits in her chair. So that only the limbs, a foot or a hand, dirty with its broken nails and cut fingers, a nose or an eye 
or that piece of her ribcage, the line of stretchmarks already present along her widening hips, might occasionally surface, just like the limbs did in the drawer. Only they will never be able to come together to reconnect that body, not even to find all its parts, the way the spots of paint led her to the limbless headless torso in the closet, with its sign and its hole, cut down there where that doll had never been meant to have one.

And there won't be any sentences either, to reconnect her to the body of her questions, to lead her back to her place of shame. But only words, occasional stray words, in many sparkling colours like graffiti, lost and unconnected as they rise up in the space of that same covering blanket, bright like the explosions of the stars behind her eyes, and all those words will be mine. And what will come out of that mouth that will appear too at the blanket's edge, just as the doll's mouth did among her underwear, will be the small short sentences I tell her to repeat again and again. Again and again.

Who cares who cares who cares she will say now, who cares who cares who cares, what difference does it make anyway, who cares who cares who cares, while they just smile and go about their business, with their pricks or with their lives. And it will be just like cowboys and Indians, just like war, just like cops and robbers, just like terrorists and CIA agents, just like doctor and nurse, just like house. Her unremembered body over there just like any other toy, any other doll. Only it will be wrapped in this purple and blue, this multicoloured, blanket of dismemberment, that will be forever empty of syntax and of emotion. A beautiful blanket so that I will never have to listen to her whine, or feel her shame. Not ever again.

There is only one problem. It is thirty years later. And I find myself putting my hand into my mouth, gagging on my food. While, seated in her chair, so long after the others have left, she still cannot get warm. 